\title{
Compressive Strength Gain Behavior and Prediction of Cement-Stabilized Macadam at Low Temperature Curing
}

\author{
Yongli Xu $\mathbb{B}^{D}$, Guang Yang ${ }^{\mathbb{D}}$, and Hongyuan Zhao \\ School of Civil Engineering, Northeast Forest University, Harbin 150040, China \\ Correspondence should be addressed to Yongli Xu; xuyongli77@163.com
}

Received 3 December 2019; Accepted 17 February 2020; Published 30 March 2020

Guest Editor: Wei (David) Fan

Copyright ( $) 2020$ Yongli Xu et al. This is an open access article distributed under the Creative Commons Attribution License, which permits unrestricted use, distribution, and reproduction in any medium, provided the original work is properly cited.

\begin{abstract}
For cement-based materials, the curing temperature determines the strength gain rate and the value of compressive strength. In this paper, the $5 \%$ cement-stabilized macadam mixture is used. Three indoor controlled temperature curing and one outdoor natural curing scenarios are designed and implemented to study the strength development scenario law of compressive strength, and they are standard temperature curing $\left(20^{\circ} \mathrm{C}\right)$, constant low temperature curing $\left(10^{\circ} \mathrm{C}\right)$, day interaction temperature curing (varying from $6^{\circ} \mathrm{C}$ to $16^{\circ} \mathrm{C}$ ), and one outdoor natural temperature curing (in which the air temperature ranges from $4^{\circ} \mathrm{C}$ to $20^{\circ} \mathrm{C}$ ). Finally, based on the maturity method, the maturity-strength estimation model is obtained by using and analyzing the data collected from the indoor tests. The model is proved with high accuracy based on the validated results obtained from the data of outdoor tests. This research provides technical support for the construction of cement-stabilized macadam in regions with low temperature, which is beneficial in the construction process and quality control.
\end{abstract}

\section{Introduction}

Cement-stabilized macadam is low-dose cement-base-stabilized mixture and its cement dosage is $5 \%$ or so; it is generally used for base layer of pavement construction in China [1]. Whether or not the compressive strength of cement-based materials largely depends upon the curing process is well known, in which both the curing temperature and time are particularly important $[2,3]$. For conventional laboratory test of compressive strength, the curing is typically carried in constant temperature environment at $20^{\circ} \mathrm{C}$ in many national specifications [4-6]. But for the pavement construction project, the actual outdoor curing temperature varies with weather. Specification requires that more than $5^{\circ} \mathrm{C}$ temperature can be carried out for construction [4]. However, in the northern seasonal frozen areas such as China's Heilongjiang Province, although the temperature is more than $5^{\circ} \mathrm{C}$ in the month of April, the temperature changes a lot and is very unstable. Due to the large temperature difference between day and night and the fact that usually does not reach $20^{\circ} \mathrm{C}$ during curing time, the compressive strength sometimes cannot meet the requirements, causing the coring to be loose. Since the strength cannot be confirmed, one cannot reasonably arrange the next process [7]. Based on this special temperature condition, there is a strong need to study the compressive strength gain laws under such different low temperature curing conditions. In that regard, several indoor and outdoor experiments are designed accordingly in this paper to conduct such study.

There are many research efforts made to study the impact of curing temperature on cement-based materials, such as Portland cement-stabilized soil, light weight cemented soil, sand, coal fly ash, and lime blends [8-10]. As for the curing temperature, many research studies have been reported for the high temperature, and most results showed that high temperature curing can increase the initial compressive strength [11, 12]. The compressive strength and tensile strength of cement-stabilized marine soils which were used as road construction materials were studied under cured temperatures varying from $40^{\circ} \mathrm{C}$ to $60^{\circ} \mathrm{C}$ in Wang's research work [13]. Escalante-Garcia et al. [14] tested the compressive strength of hydration at five temperatures ranging from $10^{\circ} \mathrm{C}$ to $60^{\circ} \mathrm{C}$, and the results showed that high temperature can improve the initial compressive strength, but it can actually 
decrease the strength in the long term. Wang et al. [15] conducted tests of calcium sulphoaluminate cement at different curing temperatures (i.e., $0^{\circ} \mathrm{C}-80^{\circ} \mathrm{C}$ ) in order to study the influence of hydration evolution on compressive strength. The results indicated the early-age compressive strength increases with increasing temperature but decreases at the temperature ranging from $40^{\circ} \mathrm{C}$ to $80^{\circ} \mathrm{C}$, and the compressive strength is mainly affected by hydration degree.

About low temperature curing, several studies have been reported in the literature. Price [16] showed that the strength of concrete mixed developed significantly slower at low temperature than that at room temperature. Husem et al. [17] tested the compressive strength of ordinary and high performance concrete under standard curing (at $23 \pm 2^{\circ} \mathrm{C}$ ) and other low temperature curing (at $10,5,0$, and $-5^{\circ} \mathrm{C}$, resp.). The results indicated that the strength at $10^{\circ} \mathrm{C}$ and less than $10^{\circ} \mathrm{C}$ was lower than that in the standard curing. Kim et al. [18] investigated the strength development for curing histories with $5^{\circ} \mathrm{C}, 20^{\circ} \mathrm{C}$, and $40^{\circ} \mathrm{C}$ temperature, which indicated that the concrete strength at low temperature was less than that at standard temperature initially but was almost the same with time. Marzouk et al. [19] performed the tests at five temperatures ranging from $-10^{\circ} \mathrm{C}$ to $20^{\circ} \mathrm{C}$ over 3 months and found that there was a proportional relationship between compressive strength and temperature.

In addition, in terms of strength prediction, many literatures have shown that maturity theory is appropriate and better in the strength prediction than some other methods [20, 21]. In 1951, Saul et al. [22] first proposed the "maturity" concept, which was defined as the product of the curing time and temperature. It was pointed out in the famous Nurse-Saul maturity function that when the maturity is the same, the strength will also be approximately the same. It is well noticed that the Nurse-Saul maturity model has been constantly improved and modified later, and different mathematical models have been adopted to predict the strength. For example, in Chitambira's model, the equivalent age as an index was proposed which combined both the curing age and curing temperature [23]. There was a linear relationship between double logarithmic strength and logarithmic maturity under different curing temperatures. Jeong et al. [24] calibrated the relationship of relative strength and maturity by the moisture factor.

A review of the existing literature revealed that although there have been many studies on other cement-based materials, less research efforts were made to the $5 \%$ cementstabilized macadam. Many studies were devoted to the effect of curing temperature on strength. However, most of them focused on high temperatures, and, furthermore, almost all the curing (be they under either high temperature or low temperature) was made under varied constant controllable temperature at the laboratory chamber. It is important to note that such curing failed to account for the alternate changes in the temperatures during actual days and nights (like the construction project), and there have been no tests conducted under outdoor natural conditions. As such, this purpose of this study is to focus on the strength gain law of $5 \%$ cement-stabilized macadam mixture at low temperature, which meets the actual temperature of the construction project. The maturity theory will be employed to predict the compressive strength. Appropriate function will be selected and relevant parameters will be calibrated and obtained by using and analyzing the experimental data. The research results will provide technical support for the construction of cement-stabilized macadam in regions of low temperature, which is beneficial to the construction quality and process control.

\section{Descriptive Analysis of Temperatures in Harbin Area}

Harbin City, Heilongjiang Province, China, is located in the north latitude $44^{\circ} 04^{\prime} \sim 46^{\circ} 40^{\prime}$, mainly plain, belonging to the north temperate zone continental monsoon climate, and the temperature changes fast in the spring and autumn. Annual precipitation reaches $400 \mathrm{~mm}-600 \mathrm{~mm}$, moisture coefficient is in the range of $0.25-1.25$, and the average maximum permafrost is $120 \mathrm{~cm}-240 \mathrm{~cm}$.

The temperature distribution from the $15^{\text {th }}$ to $30^{\text {th }}$ of April from 2012 to 2014 at Harbin City is shown in Figure 1. The trend of the high temperature and the low temperature during the construction period is basically similar. Most of the high temperatures are distributed in the range from $15^{\circ} \mathrm{C}$ to $20^{\circ} \mathrm{C}$, and most of the low temperatures fall in the range from $5^{\circ} \mathrm{C}$ to $10^{\circ} \mathrm{C}$. The average high temperature is $16^{\circ} \mathrm{C}$ and the average low temperature is $6^{\circ} \mathrm{C}$.

Figure 2 showed the daily temperature data from the $15^{\text {th }}$ to $30^{\text {th }}$ of April, 2014, at Harbin City. The data of other years follow similar pattern. At about 2 am-4 am the temperatures were the lowest, from 5 am the temperatures began to rise consistently for 9 hours at a high rate, at 12 pm-14 pm the temperatures reached the highest, and then the temperatures started to decrease continuously for 15 hours at a relatively low rate.

\section{Indoor and Outdoor Testing Plans}

According to the law of temperature variation, three indoor testing cases and one outdoor test were designed. The temperatures of three indoor tests were determined according to nearly 3 years of data at Harbin, as shown in Figure 3, and the outdoor tests started at the $17^{\text {th }}$ of April, 2015.

The cylinder specimens of $150 \mathrm{~mm} \times 150 \mathrm{~mm}$ size with $5 \%$ cement-stabilized macadam were prepared according to the stabilized macadam mix design. Under three different curing temperatures, unconfined compressive strength tests were carried out on a daily basis.

Case 1 (standard temperature curing): the standard curing was in full accordance with the requirements of the specification operation in which the temperature was $20^{\circ} \mathrm{C}$. The unconfined compressive strength test was carried out from the $3^{\text {rd }}$ day to the $7^{\text {th }}$ day. The compressive strength of the $7^{\text {th }}$ day (i.e., the $7^{\text {th }}$ standard strength) was used as a standard for reference. 


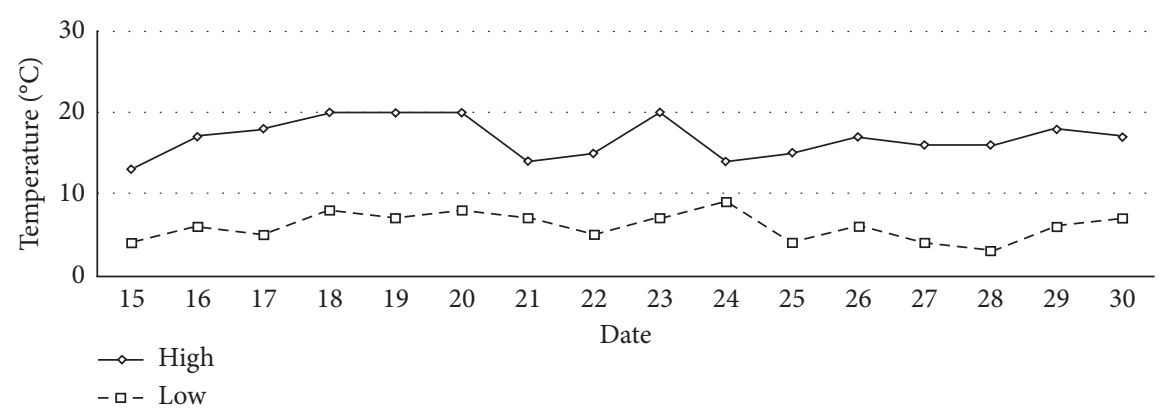

Figure 1: Temperature distribution in April from 2012 to 2014 at Harbin City.

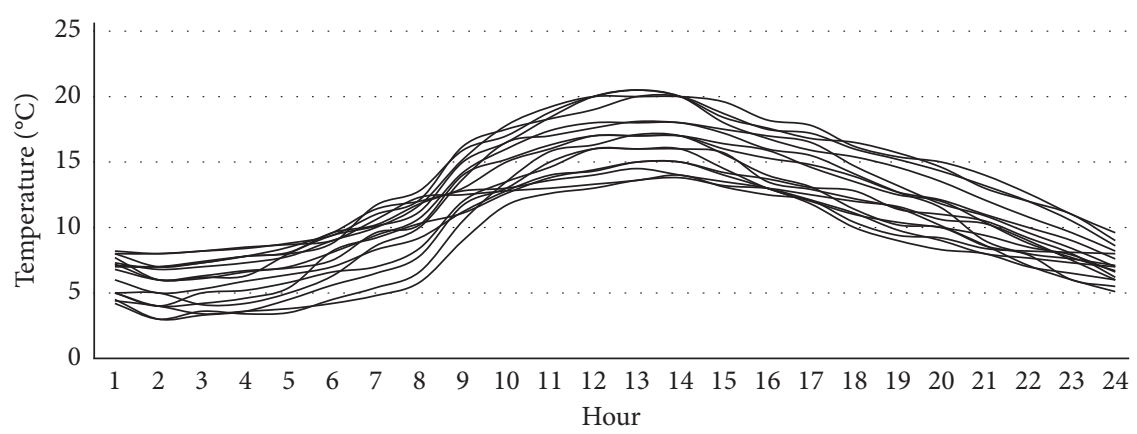

Figure 2: Daily temperatures from the $15^{\text {th }}$ to $30^{\text {th }}$ of April, 2014, at Harbin City.

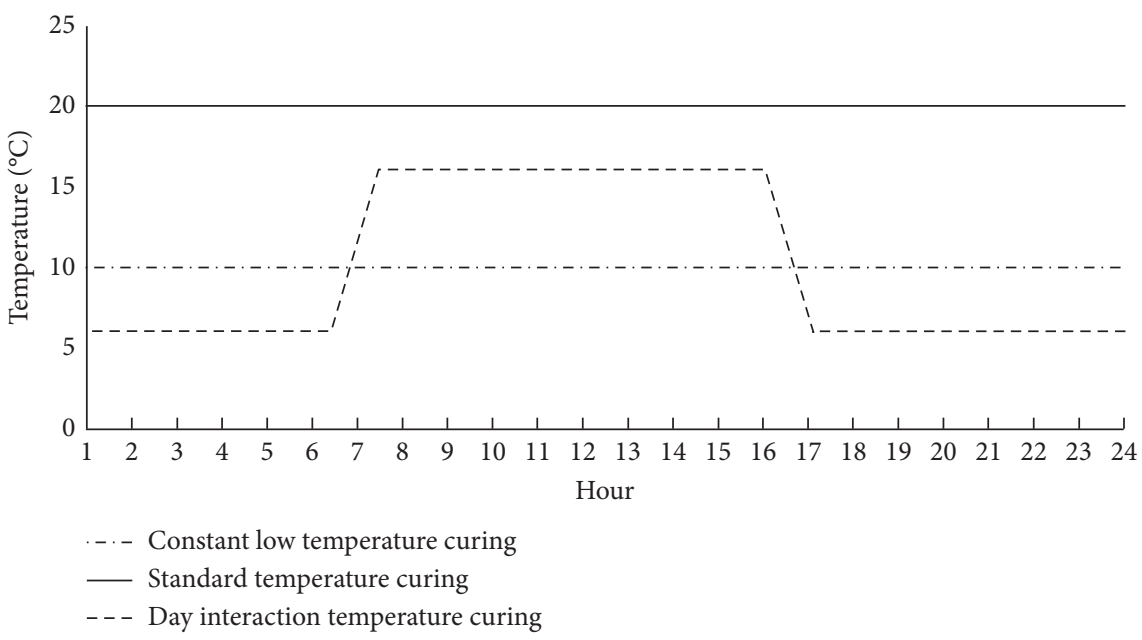

FIgURE 3: Temperature schematic diagram of three indoor testing cases.

Case 2 (constant low temperature curing): the curing temperature was $10^{\circ} \mathrm{C}$ that was determined according to the average high and average low temperatures weighted by time during nearly three years. The compressive strength was tested and the tests would not stop until the compressive strength became more than the $7^{\text {th }}$ standard strength.

Case 3 (day interaction temperature curing): the temperatures were changed in the test chamber to simulate the large variations in the day and night temperatures. As shown in Figure 3, the high temperature was kept at $16^{\circ} \mathrm{C}$ from 7 am to $15 \mathrm{pm}$ for 8 hours, and the low temperature was $6^{\circ} \mathrm{C}$ from $16 \mathrm{pm}$ to 6 am for 14 hours. From 6 am to 7 am, the temperatures were increased from $6^{\circ} \mathrm{C}$ to $16^{\circ} \mathrm{C}$, and from $15 \mathrm{pm}$ to $16 \mathrm{pm}$, the temperature was reduced from $16^{\circ} \mathrm{C}$ to $6^{\circ} \mathrm{C}$. Also, the compressive strength would continue to be tested beyond the $7^{\text {th }}$ day until the strength was more than the $7^{\text {th }}$ standard strength.

Case 4 (outdoor natural temperature curing): according to the weather forecast data, the test started on April 17, 2015. The specimens were placed in test pit. The pavement base layer and curing methods were simulated and the compressive strength was tested from the $7^{\text {th }}$ day until the strength was more than the $7^{\text {th }}$ standard strength. The specific operating procedure and temperature measuring method are discussed as follows. 
First, a depth of $15 \mathrm{~cm}$ pit was dug and the bottom was flattened. The specimens were then neatly placed into pit, and the gap was filled with fine aggregate and compact. The upper was covered with a white geotextile to keep moisture, and the water was sprayed on the surface at noon every day. Specimen placement pictures were shown in Figure 4.

Three specimens were used for temperature measurement. On each specimen, four temperature sensors were embedded in the upper, the middle external, the bottom, and the central parts of the body, which were used to measure the temperature of different parts of each specimen. Figure 5 is the schematic diagram showing the location of temperature sensors, among which the central sensor was embedded in the specimen production process and the external three sensors were fixed on the surface later. The pictures showing the central sensors and middle external sensors were given in Figure 6. During the outdoor curing period, the hand-held thermometer was used to measure the temperatures and the measurement frequency was 1 reading/hour.

\section{Material Performance and Test Methods}

4.1. Cement Performance. The cement used in the experiment was Harbin TIANE 425 \#. The technical indexes of cement are shown in Table 1 . Note that the cement dosage is $5 \%$ of the aggregate weight.

4.2. Aggregate Grade. The aggregates used were of four sizes: $2 \mathrm{~cm}-3 \mathrm{~cm}, 1 \mathrm{~cm}-2 \mathrm{~cm}, 0.5 \mathrm{~cm}-1 \mathrm{~cm}$, and $0 \mathrm{~cm}-0.5 \mathrm{~cm}$. The gravel used was in line with the "Road Pavement Construction Technical Specifications (JTJ034-2000)" requirements. The aggregate composite grade is shown in Table 2.

4.3. Compaction Test. To prepare for the specimen making, the maximum dry density and the optimum water content of the mixture were determined through compaction tests. According to the procedures described in "Test Procedure for Stabilized Materials for Highway Engineering Inorganic Binder (JTG E51-2009)", the optimum water content was $6.8 \%$ and the maximum dry density was $2.144 \mathrm{~g} / \mathrm{cm}^{3}$.

4.4. Unconfined Compressive Strength Test. The specimens were made and kept in the curing chamber. In accordance with the requirements, the curing temperatures in three cases were controlled at $20^{\circ} \mathrm{C}$ and $10^{\circ} \mathrm{C}$ and in the range from $6^{\circ} \mathrm{C}$ to $16^{\circ} \mathrm{C}$. The specimens were subjected to the unconfined compressive strength tests according to the designed testing plan.

\section{Results and Discussion}

5.1. Indoor Test Results. Figure 7 is the compressive strength gain law of three-case indoor tests. As for the standard curing temperature of $20^{\circ} \mathrm{C}$ (Case 1), the strength increases as the curing time increases, and the gain rate is initially high but gradually decreases until the $7^{\text {th }}$ day. The strength is 3.5 $\mathrm{MPa}$ which can meet the standard requirements. Under the constant low temperature of $10^{\circ} \mathrm{C}$ conditions (Case 2), the compressive strength increases continuously with the increase of the curing time, but the gain rate is less than that under the standard curing condition. The compressive strength is $2.2 \mathrm{Mpa}$ at the $7^{\mathrm{th}}$ day, accounting for only $62.9 \%$ of the $7^{\text {th }}$ standard strength. The compressive strength does not achieve the $7^{\text {th }}$ standard strength until the $14^{\text {th }}$ day. In the day interaction temperature curing of $6^{\circ} \mathrm{C}-16^{\circ} \mathrm{C}$ (Case 3 ), the compressive strength also increases with the increase of the curing time, but the gain rate is less than that for the standard curing and is also slightly less than that under the constant low temperature curing condition. The compressive strength is $2.1 \mathrm{Mpa}$ at the $7^{\text {th }}$ day, which is only $60 \%$ of the $7^{\text {th }}$ standard strength under the standard curing condition. The compressive strength does not reach the $7^{\text {th }}$ standard strength until the $14^{\text {th }}$ day.

\subsection{Outdoor Test Results}

\subsubsection{Temperature Transfer Law of the Specimens in Outdoor} Natural Environments. Figure 8 shows the day temperature curve at each position of the specimens on April 20, 2015. It can be seen that the temperature variation in the specimens was similar to that of the air temperature, and the fluctuation range in the upper part was larger than that in the middle and the lower parts. The difference between the central and the middle external was small, which indicated that the temperature transfer was small in the horizontal direction. Temperature transfer law of the specimens in outdoor natural environments is presented as follows.

(1) From 6 am, the temperature started to increase, and the temperature difference between the upper, the middle, and the bottom parts also gradually increased.

(2) At 11 am $14 \mathrm{pm}$, the temperature difference between the upper and bottom part reached the maximum of $8^{\circ} \mathrm{C}$, while the upper and middle temperature difference was about $6^{\circ} \mathrm{C}$ and the middle and bottom temperature difference was about $2^{\circ} \mathrm{C}$. This clearly indicated that the temperature demonstrated a nonlinear pattern in the depth direction. In other words, the heat received by the surface was the most significant; then the heat reduced noticeably when it was transferred to the middle and was almost nonexisting until the bottom.

(3) At $13 \mathrm{pm}$, the upper temperatures reached the maximum in the day, and at $14 \mathrm{pm}$, the middle and the bottom temperatures reached the maximum in the day. After that, the temperature of all parts gradually decreased in which the upper part temperature dropped at the fastest speed and the middle and lower temperatures slowly went down.

(4) From 20 pm to nearly 5 am or so, the temperatures at each position were basically the same in which the temperature difference between the upper, middle, and bottom parts is within $2^{\circ} \mathrm{C}$.

The "Temperature $\times$ Time" data was used as an index to analyze the curing status at each position of the specimens. 


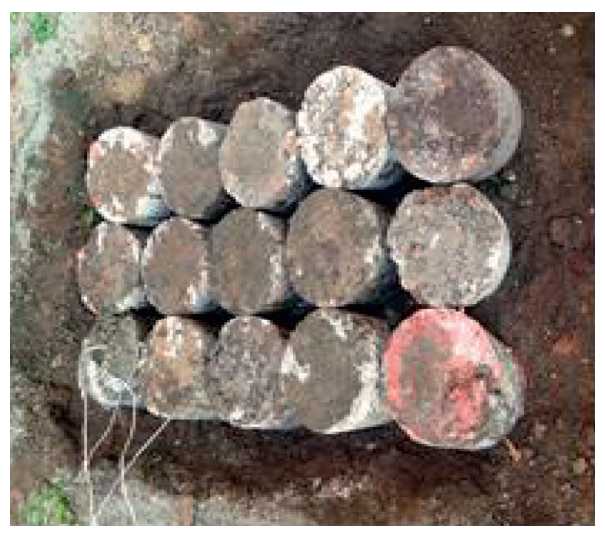

(a)

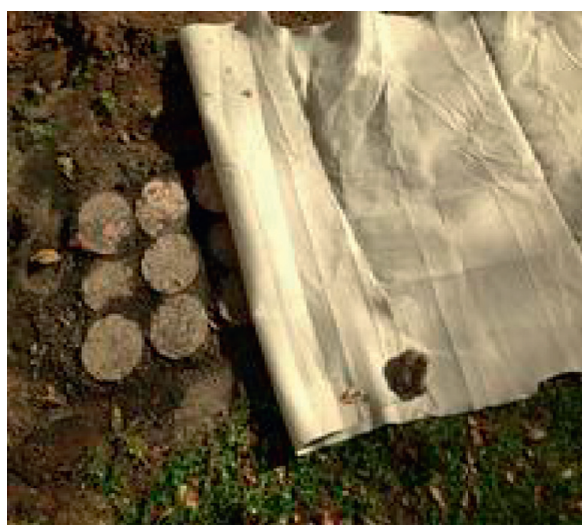

(b)

FIGURE 4: Specimen placement pictures. (a) Specimens were placed into pit. (b) Gap was filled and covered with geotextile.

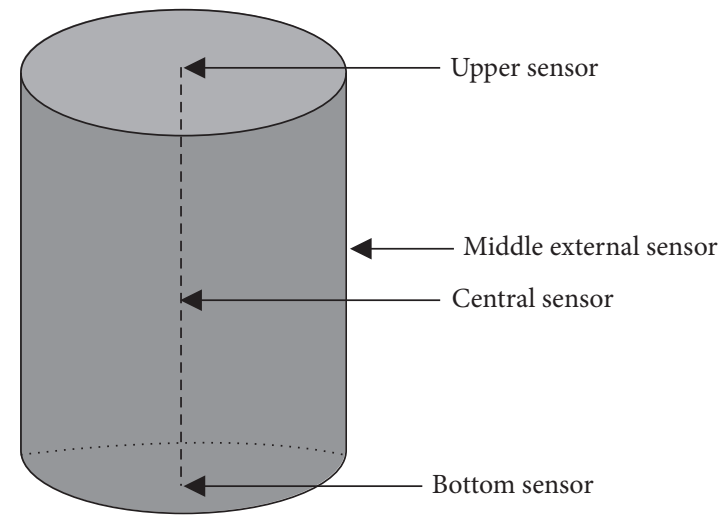

FigURE 5: Schematic diagram showing the location of temperature sensors.

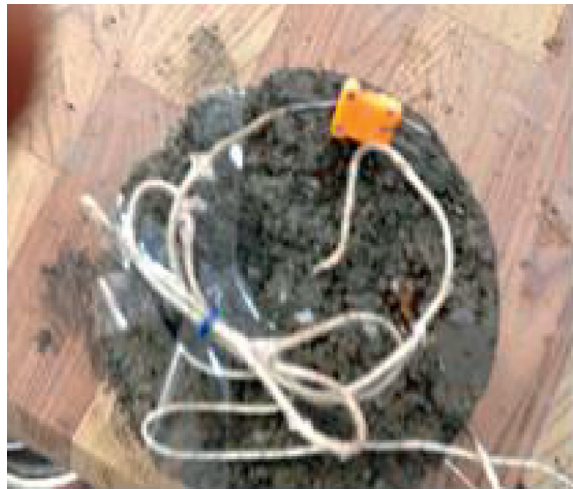

(a)

FiguRe 6: Sensors embedded in specimen.

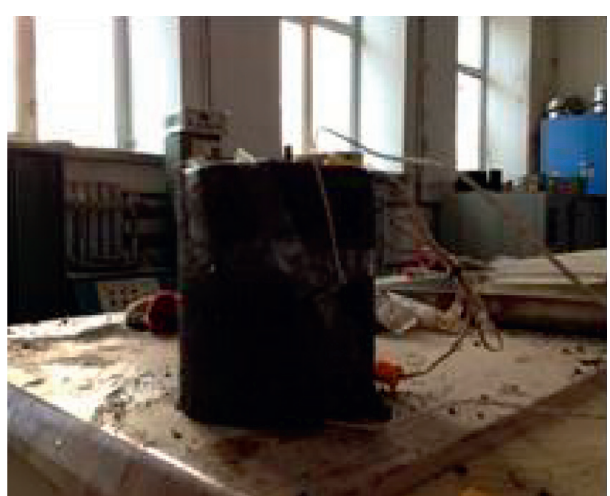

(b)
The "Temperature $\times$ Time" cumulative sum at each position of the specimens in outdoor natural environments was calculated from the $7^{\text {th }}$ day and was shown in Table 3 . The "Temperature $\times$ Time" of the $7^{\text {th }}$ day standard curing was calculated to be $3360^{\circ} \mathrm{C} \cdot \mathrm{h}$.

As can be seen from Table 3, when the curing continued to the $12^{\text {th }}$ day, the "Temperature $\times$ Time" value at the upper position reached $3569^{\circ} \mathrm{C} \cdot \mathrm{h}$, which exceeded the standard curing at the $7^{\text {th }}$ day of $3360^{\circ} \mathrm{C} \cdot \mathrm{h}$. However, it was only (a) Central sensors. (b) Middle external sensor.

$2498^{\circ} \mathrm{C} \cdot \mathrm{h}$ at the bottom position and $2979^{\circ} \mathrm{C} \cdot \mathrm{h}$ at the central position. Based on maturity theory, it could be considered that the compressive strength at the upper position has achieved the $7^{\text {th }}$ standard strength, while that at the middle and bottom positions did not reach the $7^{\text {th }}$ standard strength. This can also be a good explanation as to why coring in the construction site can sometimes fail in which only the upper part is solid and the bottom part is fairly loose, as shown in Figure 9. 
TABLE 1: Technical indexes of cement.

\begin{tabular}{lcccc}
\hline Index & Initial setting time & Final setting time & \multicolumn{2}{c}{ 3D strength (MPa) } \\
& $1 \mathrm{~h} 3 \mathrm{~min}$ & $2 \mathrm{~h} 40 \mathrm{~min}$ & Compressive strength & Flexural strength \\
\hline Value & & 21.3 & 4.8 \\
\hline
\end{tabular}

TABle 2: Composite grade of concrete aggregate.

\begin{tabular}{lccccccc}
\hline Screen size $(\mathrm{mm})$ & 26.5 & 19 & 9.5 & 4.75 & 2.36 & 0.6 & 0.075 \\
\hline Composite grade & 97.7 & 77.0 & 48.0 & 28.6 & 21.0 & 10.5 & 2.2 \\
\hline
\end{tabular}

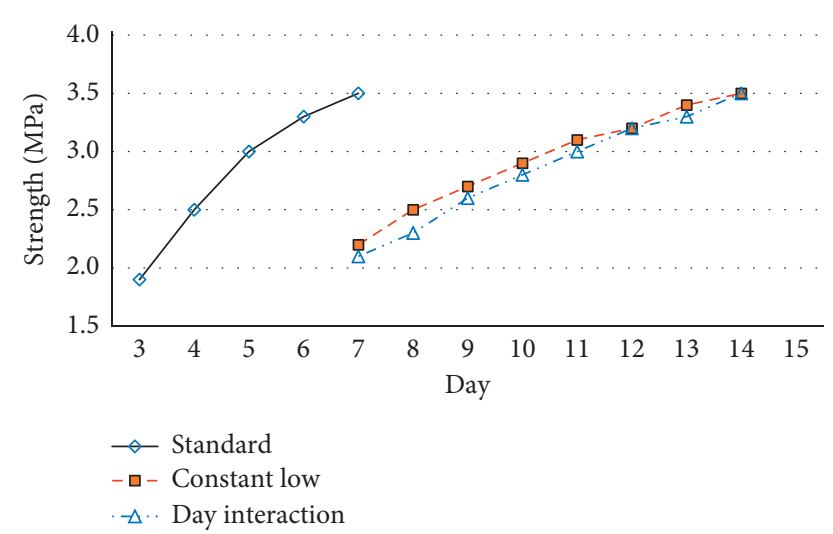

FIgURE 7: Strength gain curve of three case indoor tests.

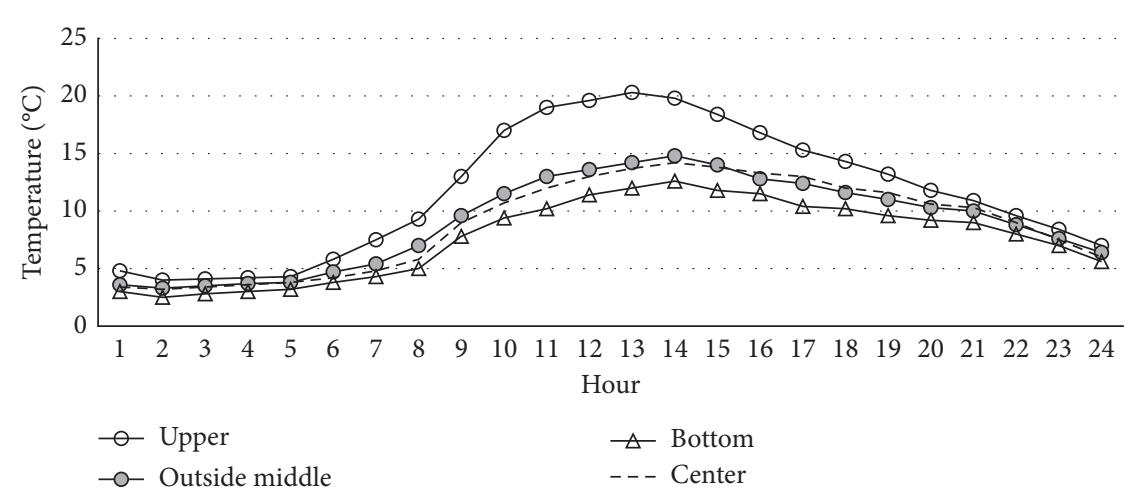

FIgURE 8: The day temperature curve at each position of the specimens.

5.2.2. Strength Gain Law under Outdoor Natural Temperature Curing. Figure 10 shows the strength gain law under outdoor nature temperature curing. The compressive strength gained with increasing curing days. The strength at day 7 was $2.2 \mathrm{MPa}$ accounting for only $62.9 \%$ of standard curing and achieved the $7^{\text {th }}$ standard strength when the number of days reached 13 .

\section{Comparisons of Strength Gain Law and Establishing the Maturity-Strength Model}

6.1. Comparison of Strength Gain Law under Four Curing Conditions. Figure 11 provides the comparisons of compressive strength gain curves under different curing conditions. The following conclusions can be made.
(1) In all four cases, the compressive strength increased with the increasing curing time. The gain rate of low temperature curing was lower than that under the standard curing temperature curing. The gain rates can be sorted in descending (from high to low) order: standard temperature curing $>$ outdoor natural temperature curing $>$ constant low temperature curing $>$ day interactive temperature curing, in which the difference between the last two was insignificant.

(2) The strength gain curves under four cases were in accordance with the logarithmic curve with the function form being $f=a \ln (M)-b$. After the model calibration, it was found that the average gain rate for the standard temperature was 
TABle 3: The "Temperature $\times$ Time" data for each position $\left({ }^{\circ} \mathrm{C} \cdot \mathrm{h}\right)$.

\begin{tabular}{lcccc}
\hline Location curing days $(\mathrm{d})$ & Upper & Middle & Bottom & Central \\
\hline 7 & 2057 & 1727 & 1427 \\
8 & 2360 & 1987 & 1641 & 1853 \\
9 & 2660 & 2247 & 2068 \\
10 & 2965 & 2515 & 2280 & 2200 \\
11 & 3265 & 2779 & 2498 & 2462 \\
12 & 3569 & 3045 & 2720 \\
13 & 3877 & 3315 & 2979 \\
\hline
\end{tabular}

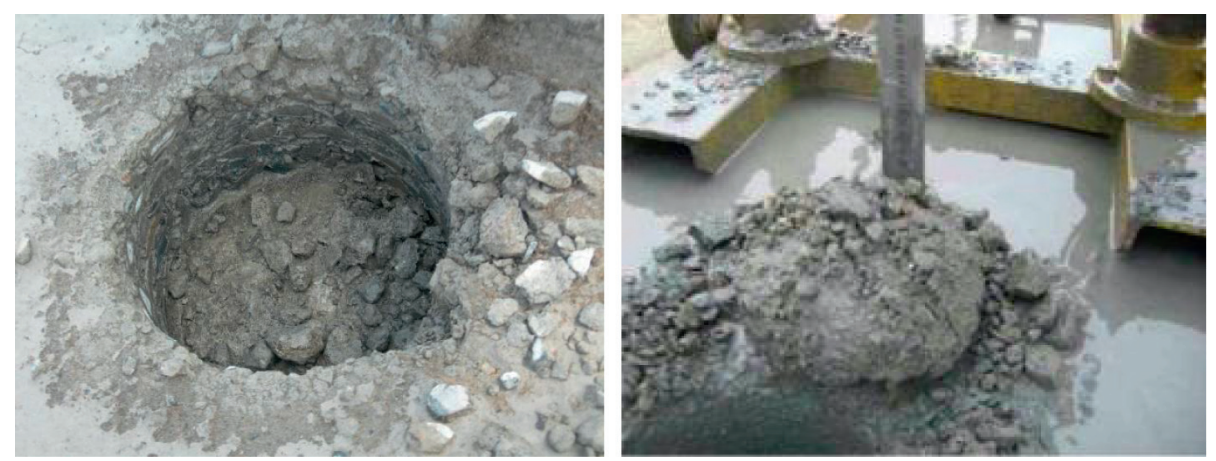

Figure 9: Coring loose picture.

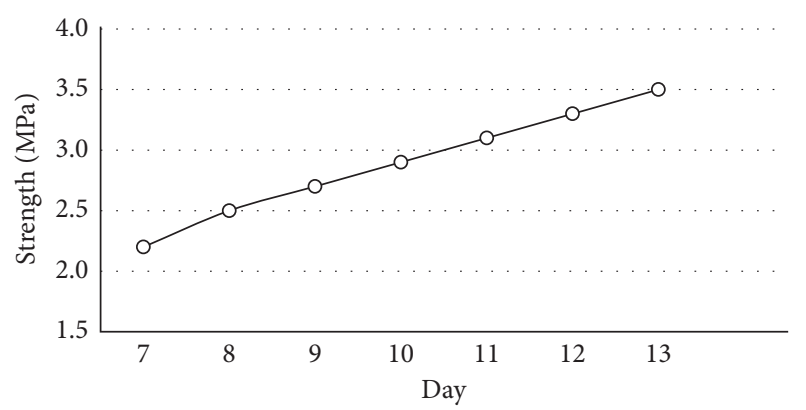

FIGURE 10: Strength gain curve under outdoor natural temperature curing.

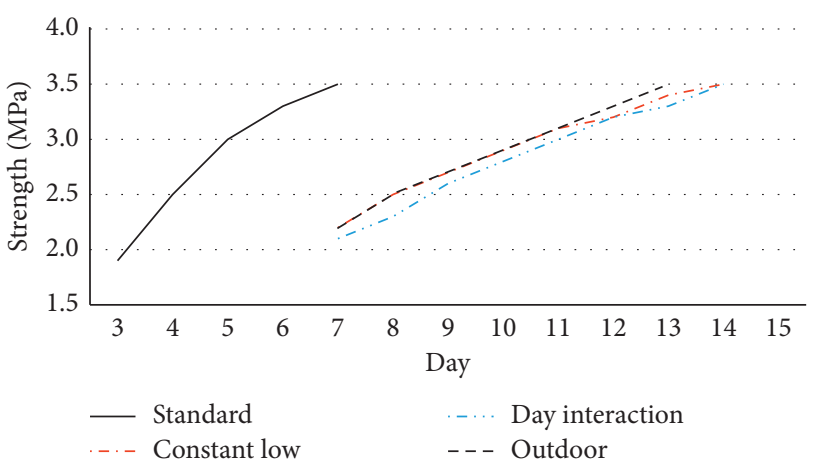

Figure 11: Comparison of strength gain law in four cases.

$a=1.0152$, for the constant low temperature of $10^{\circ} \mathrm{C}$ it was $a=1.4635$, for the day interactive temperature it was $a=1.5106$, and for the outdoor natural temperature the average gain rate was $a=1.6107$.
(3) To achieve the same strength of 3.5 MPa, the number of days required under each of these four cases was shown as follows: 7 days for standard temperature, 14 days for both the constant low and day interaction temperatures, and 13 days for the outdoor temperature.

(4) On the $7^{\text {th }}$ day, the standard strength reached 3.5 MPa, while the other three were $2.2 \mathrm{MPa}$, 2.1 $\mathrm{MPa}$, and 2.2 $\mathrm{MPa}$, respectively, which accounted for only $62 \%$ or so.

(5) Among three low temperature curing cases, the curves of the constant low temperature and the outdoor natural temperature were the same until the $11^{\text {th }}$ day, both of which were also very close to the day interaction temperature case although the day interactive gain was the slowest among these three cases. The maturity theory will be used to explain this result in the next section.

6.2. Maturity-Strength Model Estimation and Forecasting. The cement-stabilized macadam mixture consists of mainly cement, graded macadam, and water. The composition is similar to that of the cement concrete. The only difference lies in the cement dosage. Maturity theory has been widely used to predict the strength of cement concrete. As such, from the material composition point of view, the prediction function can be established based on maturity theory to forecast the compressive strength of 5\% cement-stabilized macadam mixture. Because cementstabilized macadam can be seen as cement concrete with low-dose cement, there are four functions that can be used based on the existing studies of cement concrete, including 
TABLe 4: The maturity data for the standard curing (Case 1$)\left({ }^{\circ} \mathrm{C} \cdot \mathrm{h}\right)$.

\begin{tabular}{lccccc}
\hline Days & $3 \mathrm{~d}$ & $4 \mathrm{~d}$ & $5 \mathrm{~d}$ & $6 \mathrm{~d}$ & $7 \mathrm{~d}$ \\
\hline Stand curing & 1440 & 1920 & 2400 & 2880 & 3360 \\
\hline
\end{tabular}

Table 5: The maturity data in Case 2 and Case $3\left({ }^{\circ} \mathrm{C} \cdot \mathrm{h}\right)$.

\begin{tabular}{lccccccc}
\hline Days & $7 \mathrm{~d}$ & $8 \mathrm{~d}$ & $9 \mathrm{~d}$ & $10 \mathrm{~d}$ & $11 \mathrm{~d}$ & $12 \mathrm{~d}$ & $13 \mathrm{~d}$ \\
\hline Case 2 & 1680 & 1920 & 2160 & 2400 & 2640 & 2880 & 3120 \\
Case 3 & 1638 & 1872 & 2106 & 2340 & 2574 & 2808 & 3042 \\
\hline
\end{tabular}

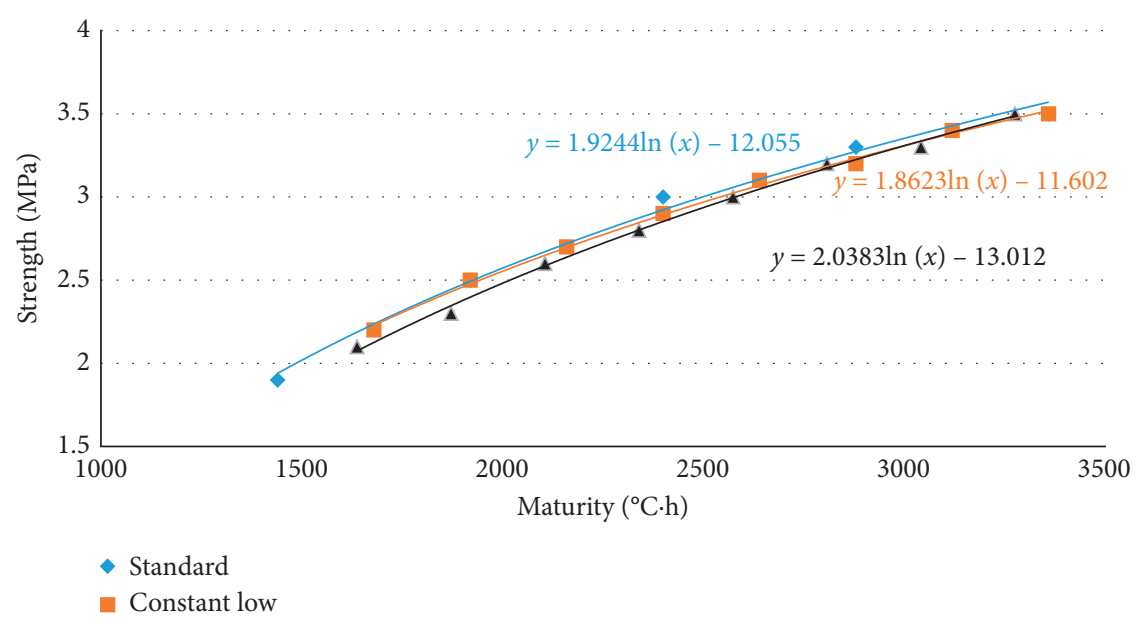

FIgURE 12: Relationship between maturity and strength.

TABLE 6: The compressive strength of tested and predicted outdoor curing.

\begin{tabular}{|c|c|c|c|c|c|c|c|}
\hline Days & $7 \mathrm{~d}$ & $8 \mathrm{~d}$ & $9 \mathrm{~d}$ & $10 \mathrm{~d}$ & $11 \mathrm{~d}$ & $12 \mathrm{~d}$ & $13 \mathrm{~d}$ \\
\hline Maturity $\left({ }^{\circ} \mathrm{C} \cdot \mathrm{h}\right)$ & 1690 & 1946 & 2200 & 2462 & 2719 & 2979 & 3246 \\
\hline Tested value (MPa) & 2.200 & 2.500 & 2.700 & 2.900 & 3.100 & 3.300 & 3.500 \\
\hline Predicted value $(\mathrm{MPa})$ & 2.205 & 2.478 & 2.715 & 2.933 & 3.125 & 3.302 & 3.468 \\
\hline
\end{tabular}

the power function, logarithmic function, exponential function, and hyperbolic function [25].

The maturity of three indoor experiments was calculated and shown in Tables 4 and 5. The relationship between the maturity and strength in three cases is shown in Figure 12. It seems that the logarithmic functions $f=a \ln (M)-b$ are the best predictive curves under all three cases, and, therefore, it was used as the preferred function for cement-stabilized macadam mixture. In addition, by combining the data under all three cases and developing a single predictive model, the parameters $a=1.9358$ and $b=12.183$ were obtained by fitting the compressive strength and maturity data, and the correlation coefficient was $R^{2}=0.9907$. In short, the MaturityStrength prediction model of $5 \%$ cement-stabilized macadam mixture was $f=1.9358 \ln (M)-12.183$.

For the outdoor natural curing cases, the central position data was used for maturity calculation, It should be noted that one hour was used as the temperature range, was then accumulated into one day, and was again accumulated across days to get maturity value. Using the obtained function $f=$ $1.9358 \ln (M)-12.183$ to predict the compressive strength under the outdoor curing case, the results were shown in Table 6. Note that these results were very close to the tested strength and the correlation coefficient was as high as $99.865 \%$, which clearly indicated the high accuracy of the model. According to the model, the compressive strength of low temperature curing can be predicted with maturity, which provides a reference to calculate the strength and determine the schedule of the construction project for engineering applications.

\section{Conclusion}

The present study discusses the compressive strength gain law of $5 \%$ cement-stabilized macadam at low temperature curing, with a particular focus on the varied temperature curing which is similar to the varied air temperature in the real world.

In this paper, experiments under three indoor temperature curing cases and one outdoor natural curing were 
conducted. Experimental results showed that the compressive strength increased with the increasing curing time under all four cases and that the gain rate at low temperature was smaller than that at standard temperature. The gain rates can be sorted in descending order: standard temperature curing $>$ outdoor natural temperature curing $>$ constant low temperature curing $>$ day interactive temperature curing. The standard strength reached $3.5 \mathrm{MPa}$ on the $7^{\text {th }}$ day, while the others accounted for only $62 \%$ or so. Numerical results also indicated that to achieve the same strength of $3.5 \mathrm{MPa}$, the number of days required under each low temperature case was 14 days for both the constant low and day interaction temperatures and 13 days for the outdoor temperature.

According to the temperature data and the strength information collected by several indoor tests, an estimated model $f=1.9358 \ln (M)-12.183$ was established to predict the strength based on the maturity theory. The model is proved to have the ability to predict with high accuracy based on the validated results obtained from the data of outdoor tests.

As the line of research matures in the future, the characteristics associated with the compressive strength in the long term can also be investigated with more data collected over time.

\section{Data Availability}

The data used to support the findings of this study are available from the corresponding author upon request.

\section{Conflicts of Interest}

The authors declare that they have no conflicts of interest.

\section{Acknowledgments}

The authors would like to express their sincere gratitude to the National Key R\&D Program of China (2017YFF0205600) for financial support.

\section{References}

[1] H. C. Wang, X. M. Huang, and Z. Fu, "Experimental study on the performance of semi-rigid base coarse materials," Journal of Highway and Transportation Research and Development, vol. 22, no. 11, pp. 45-49, 2005.

[2] ACI Committee, Cold-Weather Concreting (ACI 306R-88): Reapproved 2002, American Concrete Institute, Farmington Hills, MI, USA, 1988.

[3] D. P. Bentz, P. E. Stutzman, and F. Zunino, "Low-temperature curing strength enhancement in cement-based materials containing limestone powder," Materials and Structures, vol. 50, no. 3, p. 173, 2017.

[4] X. D. Wang, L. Z. F. Zeng, and Q. Xiao, Technical Guidelines for Construction of Highway Road Bases (JTG/T F20-2015), Highway \& Transportation Industry Standard, Beijing, China, 2015.

[5] ACI Committee, Standard Practice for Curing Concrete (ACI 308-92): Reapproved 1997, American Concrete Institute, Farmington Hills, MI, USA, 1997.

[6] German Committee for Reinforced Concrete, Recommendation on the Heat Treatment of Concrete, Deutscher Ausschuss fuer Stahlbeton, Berlin, Germany, 1989.
[7] X. Y. Zhao, L. L. Chen, and Y. Zhao, "Investigation on coring time of road base course in cold region," Low Temperature Architecture Technology, vol. 44, no. 8, pp. 99-100, 2011.

[8] K. W. Oh and T. H. Kim, "Dependence of the material properties of lightweight cemented soil on the curing temperature," Journal of Materials in Civil Engineering, vol. 26, no. 7, Article ID 06014008, 2013.

[9] I. L. Howard and T. Cost, Curing Temperature Effects on Soils Stabilized with Portland Cement Having Different Sulfate Contents, Geo-Congress, Atlanta, GA, USA, 2014.

[10] N. C. Consoli1, C. G. D. Rocha, and C. Silvani, "Effect of curing temperature on the strength of sand, coal fly ash, and lime blends," Journal of Materials in Civil Engineering, vol. 26, no. 8, 2014.

[11] R. G. Burg, The Influence of Casting and Curing Temperature on the Properties of Fresh and Hardened Concrete: PCA Research and Development Bulletin RD113, Portland Cement Association, New York City, NY, USA, 1996.

[12] ACI Committee, "Accelerated Curing of Concrete at Atmospheric Pressure (ACI 517.2R-87): Revised 1992, American Concrete Institute, Farmington Hills, MI, USA, 1992.

[13] D. X. Wang, Z. R. Zentar, and N. E. Abriak, "Temperatureaccelerated strength development in stabilized marine soils as road construction materials," Journal of Materials in Civil Engineering, vol. 29, no. 5, 2017.

[14] J. I. Escalante-Garci'a and J. H. Sharp, "Effect of temperature on the hydration of the main clinker phases in Portland cements: part II, blended cements," Cement and Concrete Research, vol. 28, no. 9, pp. 1259-1274, 1998.

[15] P. Wang, N. Li, and L. Xu, "Hydration evolution and compressive strength of calcium sulphoaluminate cement constantly cured over the temperature range of 0 to $80^{\circ} \mathrm{C}$," Cement and Concrete Research, vol. 100, pp. 203-213, 2017.

[16] W. H. Price, "Factors influencing concrete strength," ACI Journal Proceedings, vol. 47, no. 2, pp. 417-432, 1951.

[17] M. Husem and S. Gozutok, "The effects of low temperature curing on the compressive strength of ordinary and high performance concrete," Construction and Building Materials, vol. 19, no. 1, pp. 49-53, 2005.

[18] J.-K. Kim, Y.-H. Moon, and S.-H. Eo, "Compressive strength development of concrete with different curing time and temperature," Cement and Concrete Research, vol. 28, no. 12, pp. 1761-1773, 1998.

[19] H. Marzouk and A. Hussein, "Effect of curing age on highstrength concrete at low temperatures," Journal of Materials in Civil Engineering, vol. 7, no. 3, pp. 161-167, 1995.

[20] T. Kim and K. L. Rens, "Concrete maturity method using variable temperature curing for normal-strength concrete mixs. II: theoretical study," Journal of Materials in Civil Engineering, vol. 20, no. 12, 2008.

[21] R. O. Rasmussen, J. K. Cable, D. J. Turner, and G. F. Voigt, "Strength prediction by using maturity for Portland cement concrete pavement construction at airfields," Transportation Research Record: Journal of the Transportation Research Board, vol. 1893, no. 1, pp. 18-25, 2004.

[22] A. G. A. Saul, "Principles underlying the steam curing of concrete at atmospheric pressure," Magazine of Concrete Research, vol. 2, no. 6, pp. 127-140, 1951.

[23] B. Chitambira, Accelerated Ageing of Cement Stabilised/ Solidified Contaminated Soils with Elevated Temperatures, Ph.D. thesis, Cambridge University Geotechnical Engineering Group, Cambridge, UK, 2004.

[24] J. H. Jeong, S. Lim, and D. G. Zollinger, "Development of a moisture-modified maturity model for Portland cement 
concrete pavements," Baltic Journal of Road and Bridge Engineering, vol. 3, no. 1, 2008.

[25] N. J. Carino and H. S. Lew, The Maturity Method: From Theory to Application: The Structures Congress, American Society of Civil Engineers, Washington, DC, USA, 2001. 